\title{
Practical Exploration of Home Study Guidance for Students during the COVID-19 Pandemic: A Case Study of Hangzhou Liuxia Elementary School in Zhejiang Province, China
}

\author{
Qinggen Kong \\ Hangzhou Liuxia Elementary School, Hangzhou 310023, Zhejiang, China
}

\begin{abstract}
During the COVID-19 pandemic, Hangzhou Liuxia Elementary School in Zhejiang Province adopted an online education model to carry out home-based distance education and student academic counseling, and actively developed teaching practices for home-based learning. We discuss the teaching practice of students' home study during the pandemic.
\end{abstract}

Doi: $10.15354 /$ sief.20.rp026

Keywords: COVID-19; Home Study; Online Education; Elementary School

Correspondence to: Qinggen Kong, Hangzhou Liuxia Elementary School, Hangzhou 310023, Zhejiang, China.Email: 360304995@qq.com.

Conflict of Interests: None. 
A

FFECTED by COVID-19 pandemic, the school is unable to carry out normal teaching activities. The China government adopts the method of "School's Out, But Class's On", i.e. "suspending classes without stopping learning", to continue its teaching activities. Teaching moved from offline to online, teachers moved from classroom face-to-face teaching to online cloud teaching, and student learning moved from classroom listening to home study. "School's Out, But Class's On" has completely changed the way students learn and teachers "teaching methods, and has completely overturned the traditional teacher-centered teaching model. This is a test of student-centered education in China's education reform to guide students to learn at home (Zhou, et al., 2020).

In order to strictly implement the requirements of the Ministry of Education of China, Zhejiang province and Hangzhou city for the "School's Out, But Class's On" during the COVID-19 pandemic prevention and control period, Hangzhou Liuxia Elementary School in Zhejiang Province made full use of the online education platform and adopted an online education model to guide students to study at home. We actively carried out online education and teaching activities to rationally arrange students' home study time. Strived to improve the quality of students' home study and cultivated their ability to study at home. To the maximum extent, it guaranteed the normal progress of students' learning progress and laid a solid foundation for the subsequent restoration of normal teaching activities.

\section{Problems Encountered by Students at Home during COVID-19 Pandemic}

The school used "Internet+" educational technology to guide students to study at home. However, in the specific implementation process, students often could not effectively study at home due to various problems. The main issues are as follows:

\section{Fundamental Changes in the Learning Environment}

During the pandemic, students switched from traditional classroom learning to online learning at home. In the absence of teachers' face-to-face instruction and parental supervision, students who lack self-control have become a formalism of online learning, and their home study results are not satisfactory.

It was difficult for teachers to adapt to the new environment of online teaching. Teachers did not know how to express themselves in the face of live broadcasting. Their teaching language lacked flexibility, and the form was simple and formless, which could not attract students' interest. In addition, online teaching could not directly face students, and could not achieve real-time teacher-student interaction, so student participation was not high. As a result, the teacher's live broadcasting completely became a self-talking performance.

\section{Unsuitable Learning Resources}


National and local education administration departments at all levels provide schools with a large number of high-quality teaching resources. Giant education companies are also actively enriching curriculum education resources to provide resource guarantee for online learning during pandemic. But the numerous educational resources ignore the true learning needs of students. The incompatibility of learning ability, resources and students' learning situation leads to students being hindered in home study and poor study effect.

\section{Unskilled Application of Online Teaching Tools}

Online teaching not only puts forward requirements for teachers, students, teaching content and resources, but also sets higher standards for the online teaching support environment. On the one hand, teaching platforms had encountered technical errors in the face of huge data demands. Many online education platforms had problems such as freezes, flashbacks, and dropped calls. These directly led to a great impact on the teaching and learning effects. Second, in terms of platform applications, many teachers and students were not proficient in the application of teaching platforms, especially those of middle-aged and elderly teachers, and they were not able to use modern educational technologies to realize live broadcasting.

\section{Too Simple of the Teaching Activities}

During the pandemic, online e-learning has become a major activity for student home isolation. E-learning courses focused only on students' academic studies and ignore other extracurricular activities. Such a course arrangement was not "student-centered." This lacked the idea of whole-person education, ignored the developmental nature of students as individuals, and inhibited the active nature of school life. The individual life potential of students could not be developed freely, fully, comprehensively, harmoniously and sustainably. This was not conducive to the all-round development of students.

\section{Measures Taken by Students at Home during COVID-19 Pandemic}

In response to the problems that students encountered during the pandemic, and in combination with the actual situation of the school, we have taken the following measures by referring to the accumulated experience in the past:

\section{Combining School Reality to Construct an Educational Infor- mation Environment}

The school has basically built a "three links and two platforms", which provided basic technical and platform support for students' home study. At the same time, the school also used a variety of online platforms to further improve the information environment during the pandemic. We continued to strengthen the integration of education 
informatization and classroom teaching, and further improved education and teaching through means of education informatization.

Considering the lack of information technology capabilities of Elementary School students, in the early days of online teaching, the school uniformly chose QQ groups, which were stable and easy to operate, and were familiar to both students and parents as a platform for online learning. This ensured that the whole school's teachers and students could quickly enter the atmosphere of online learning.

After the online teaching was initially mature, the school guided students to use national and local education digital resources and other teaching platforms to obtain more teaching resources. In terms of platform selection, the school unified teaching platform to avoid confusion caused by frequent platform changes.

\section{Restructuring Teacher-Led and Student-Centered Teaching Methods}

In order to mobilize students' initiative and enthusiasm for learning, and help students learn at home, we carried out online teaching through feedback interactive mode. The specific process is shown below:

- Teachers sent class resource packs to students through teaching platforms. This includes protocol-guided learning, micro-lecture resources, and practice testing questions. Students downloaded their own resource packs on the teaching platform for home study and practice. The teaching platform analyzed student data and fed it back to teachers.

- Teachers used the shared screen function in Tencent meeting tools to organize students to carry out online teaching. In the teaching process, teachers taught based on the feedback results; at the same time, students were invited to express their views and opinions to help students improve their attention.

\section{Combining School-Based Resources to Build Appropriate Learning Resources}

Students' home study needs to build diverse resources suitable for their learning. During the pandemic, we organized teachers to conduct regular online discussions to prepare protocol-guided learning materials that meet the needs of students.

In order to ensure the comprehensive development of students' morality, intelligence, physical exercise, arts, and labor, the school has developed a special course on "learning martial arts to prevent virus, and living a healthy life" based on the original school-based curriculum and the current status of the pandemic. Through this special course, students were guided to exercise at home and strengthened their management of physical health while learning. This enhanced students' practical activities and enriched their spiritual life. 


\section{Use Home-School Communication to Achieve Home-School Co-Education}

During the pandemic, parents were more responsible for supervising student learning. In order to grasp the learning situation, the school communicated with parents in time and cooperated with each other. This gave play to the advantages of home-school synergy and formed a good atmosphere for home-school co-education.

- Parents accompany their children to study. Parents urged their children to complete the learning tasks assigned by the teacher. Participate with your child at the same table, and learn together to directly sense their learning status and promptly remind them when they are distracted.

- Parents guide children's healthy learning. Parents guided children to go green online. Paid close attention to the use of computers, mobile phones and other equipment. Parents instructed them to do eye exercises regularly to protect their eyesight. This not only improved the efficiency of learning, but also realized the integration of work and rest.

Elementary School students' home study outside the normal teaching scene is a new topic (Xie \& Yang, 2020). During the pandemic, we carried out corresponding practices and attempts, but were limited by various factors. In particular, the difficulty in transforming the teaching methods of teachers and the unfamiliar grasp of information technology need to be continuously improved in the future.

\section{References}

Xie, Z., Yang, J. (2020) Autonomous learning of elementary students at home during the COVID-19 epidemic: A case study of the second elementary school in Daxie, Ningbo, Zhejiang Province, China. Best Evid Chin Edu, 4(2):535-541.
Zhou, L., Wu, S., Zhou, M., Li, F. (2020) 'School's Out, But Class' On', The largest online education in the world today: taking china's practical exploration during the COVID-19 epidemic prevention and control as an example. Best Evid Chin Edu, 4(2):501-519. 